\title{
Control of ovulation in farm animals
}

\author{
W. Haresign, G. R. Foxcroft and G. E. Lamming \\ A.R.C.Research Group on Hormones and Farm Animal Reproduction, University of Nottingham, \\ Faculty of Agricultural Science, Sutton Bonington, Loughborough, Leics LE12 5RD, U.K.
}

\begin{abstract}
Summary. Examination of hormonal changes occurring in farm species at the onset of puberty, during the follicular phase of the oestrous cycle, and at those times when ovarian activity is re-established after periods of seasonal or lactational anoestrus, provides circumstantial evidence that the final phases of follicular development are dependent on a pattern of tonic (episodic) LH secretion. A suppression of episodic LH secretion is associated with periods of anovulation. Stimulation of tonic LH secretion by repeated injections of small doses of synthetic Gn-RH or purified LH restores normal reproductive function in all but deeply anoestrous animals. Continuous infusion of Gn-RH is as effective as repeated injections. It is suggested that an additional inadequacy, possibly endocrine, contributes to the anovulatory state in deep anoestrus.
\end{abstract}

\section{Introduction}

Reproductive inefficiency is one of the main limitations to high biological and economic performance of the three major farm species. Its extent can be modified considerably by a range of environmental and physiological factors. For example, sheep show a pronounced seasonal pattern of breeding (Robinson, 1951), and, with the exception of a few breeds with an extended season (e.g. Dorset Horn and Merino), it is possible to achieve only a single pregnancy per year even though the length of gestation is only 147 days. There is a further period of anovulation in the immediate postpartum period.

Although neither the pig nor the cow are typically considered to exhibit a period of seasonal anoestrus, there is nevertheless clear evidence of a seasonal modulation of their reproductive performance (Bulman \& Lamming, 1978; Paterson, Barker \& Lindsay, 1978; Peters \& Riley, 1982a, b). In the majority of milked dairy cows there is a short period of post-partum acyclicity (Bulman \& Lamming, 1978; Bulman \& Wood, 1980) which may simply reflect the latent effects of the preceding pregnancy on the activity of the hypothalamo-pituitary-ovarian axis and the need for complete uterine involution. Normally, there is a restoration of ovarian activity in milked cows within about 30 days of parturition, although in some animals this can be considerably delayed (Bulman \& Lamming, 1978; Lamming, Wathes \& Peters, 1981). By contrast, the suckled cow has a longer and more variable post-partum acyclic period which is particularly pronounced in those animals suckling more than one calf (Wettermann, Turman, Wyatt \& Totusek, 1978; Lamming $e t$ $a l ., 1981$ ). Such extended periods of anovulation can increase the interval between the birth of consecutive calves considerably beyond the economic optimum of 365 days.

A complete suppression of oestrus and ovulation during lactation generally occurs in the domestic pig, although this may reflect an inhibition attributable to the suckling stimulus and/or the presence of the litter rather than lactation per se. Weaning is normally followed by oestrus and ovulation within 4-8 days (see Varley, 1982). 
In spite of attempts during the past 25 years to overcome such instances of reproductive quiescence, little progess has been made, largely due to a lack of understanding of the endocrine causes of reproductive inactivity. This paper is a review of recent research concerning the hormonal inadequacies which result in anovulation, together with details of experiments designed for its correction.

\section{The determinants of natural ovulation in farm animals}

The control of the oestrous cycle requires the integration of the hypothalamic-pituitary-ovarian axis involving both positive and negative feedback systems; an inadequacy of response at any level can interrupt normal oestrous cyclicity. Detailed analysis of the hormonal changes occurring during the oestrous cycle in the ewe indicate a progressive rise in tonic $\mathrm{LH}$ concentrations between the onset of luteal regression and the onset of the preovulatory LH surge (Baird, 1978; Karsch, Legan, Ryan \& Foster, 1978) and this is associated with a parallel increase in oestradiol concentrations (Text-fig. 1). This rise in mean circulating LH concentrations during the follicular phase is attributable to a gradual increase in episode frequency of $\mathrm{LH}$ from its mid-cycle nadir of one episode per 3-12 h, when progesterone concentrations are high, to approximately one episode per 1-2 h immediately before the preovulatory LH surge (Baird, Swanston \& Scaramuzzi, 1976; Baird, 1978). This rise in oestradiol secretion rate in response to each LH episode, together with the parallel increases in both LH and oestradiol concentrations during the follicular phase, led to the suggestion that the final phases of follicular growth and maturation are under the control of tonic LH secretion (Baird, 1978). Such a suggestion does not preclude a role for FSH in the control of follicle growth; FSH is known to be important in stimulating the early stages of follicle growth and steroidogenesis (see Richards, Rao \& Ireland, 1978) although the rapid increase in size of the immediate preovulatory follicle occurs at a time when FSH concentrations are stable or may even be declining. The absolute levels of FSH during the follicular phase may nevertheless provide an

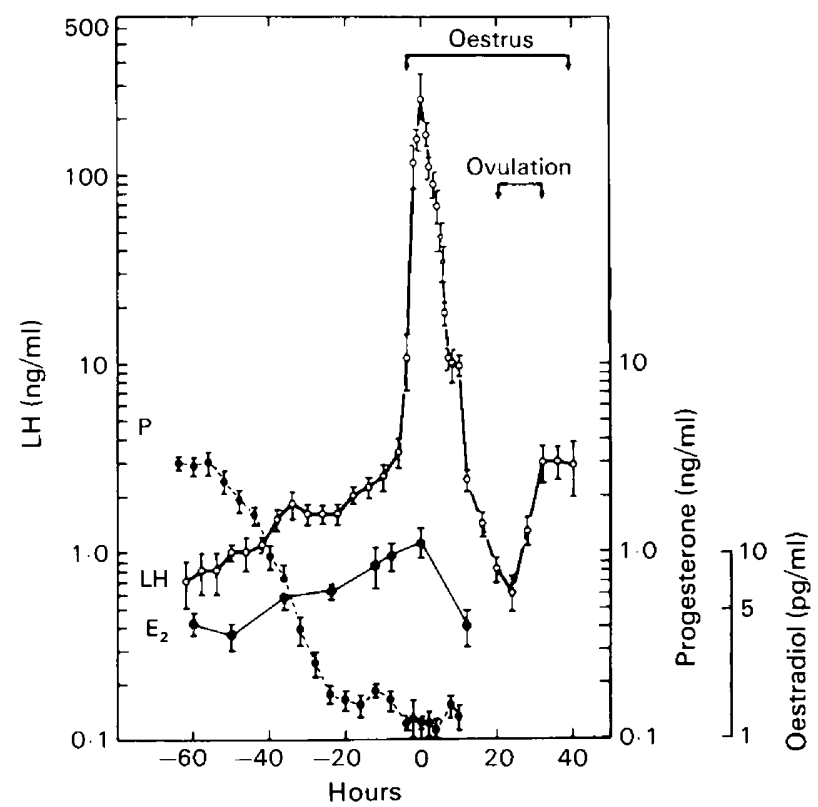

Text-fig. 1. Temporal changes in LH, oestradiol-17 $\left(\mathrm{E}_{2}\right)$ and progesterone $(\mathrm{P})$ concentrations in peripheral plasma of ewes at a natural oestrus. The data have been normalized around the timing of the preovulatory LH peak. (After Karsch et al. 1978.) 


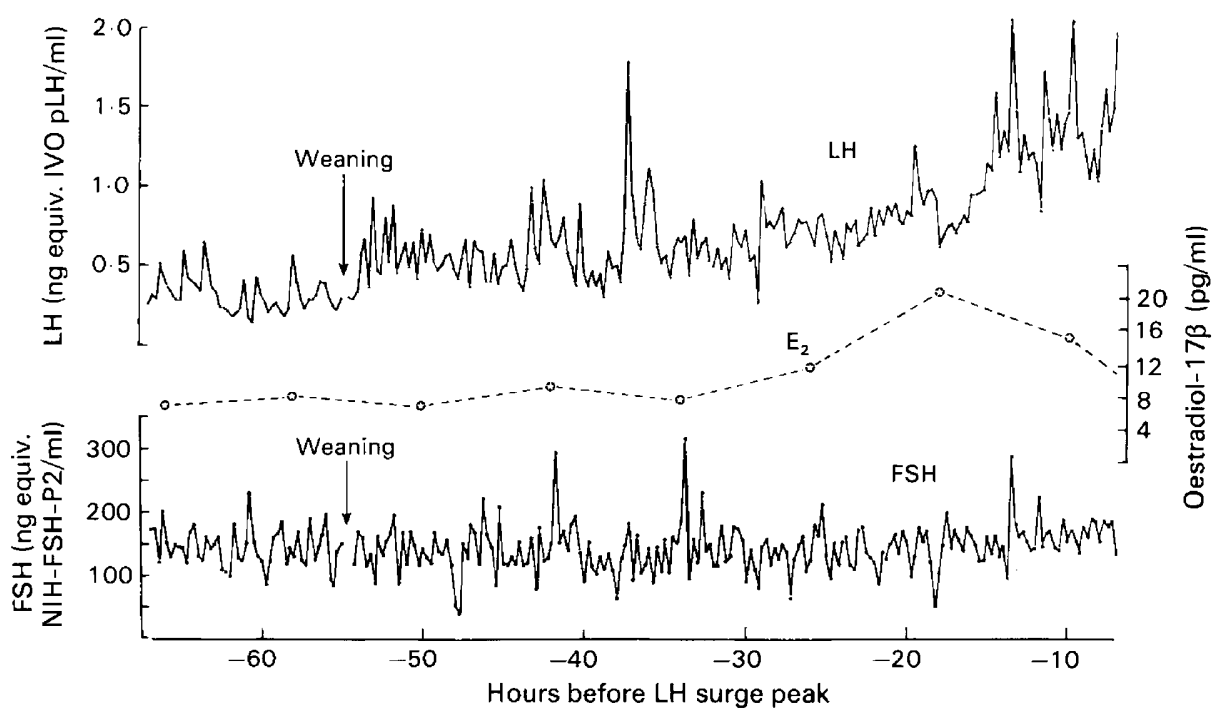

Text-fig. 2. LH, FSH and oestradiol- $17 \beta\left(\mathrm{E}_{2}\right)$ changes in peripheral plasma in a sow producing an LH surge immediately following weaning at 21 days of lactation (H. J. Shaw \& G. R. Foxcroft, unpublished data).

essential component of the ovulatory control mechanism. Such a sequence of hormonal changes and control mechanisms is not restricted to the ewe. Indeed data from both the cow (Rahe, Owens, Fleeger, Newton \& Harms, 1980; A. R. Peters, G. M. Riley \& G. E. Lamming, unpublished) and the sow (Foxcroft \& van de Wiel, 1982; H. J. Shaw \& G. R. Foxcroft, unpublished observations; see Text-fig. 2) indicate similar inter-relationships in these species.

\section{Patterns of hormone secretion during periods of anovulation}

Data accumulating from domestic farm species suggest that periods of anoestrus and anovulation are associated with an inadequate pattern of episodic LH secretion. Examples to illustrate this point are taken from studies of post-partum/lactational anoestrus in the cow and pig and seasonal anoestrus in the ewe, and of pre-pubertal females of all three species.

\section{Post-partum/lactational anoestrus}

The latent effects of the preceding pregnancy result in a reduced pituitary sensitivity to a bolus injection of exogenous $\mathrm{Gn}-\mathrm{RH}$ in all three farm species, but this disappears by about Day 10 post partum in milked cows, Day 20 post partum in suckled cows (Webb, Lamming, Haynes, Hafs \& Manns, 1977; Fernandes, Thatcher, Wilcox \& Call, 1978; Foster, Lamming \& Peters, 1980), gradually throughout lactation in the pig (Stevenson, Cox \& Britt, 1981) and by Day 28 post partum in the ewe (Jenkin, Heap \& Symons, 1977). Although this may, at least in part, explain the absence of ovulation in the immediate post-partum period, it is unlikely to be a major contributory factor to the more extended periods of post-partum anovulation, nor does it explain seasonal anoestrus in the ewe.

During the early post-partum period in the cow, LH concentrations generally remain low, with no evidence of an episodic pattern of secretion. In the milked animal the episodic pattern of LH secretion reappears by about Day 10-15 post partum, initially at a rate typical of the luteal phase of the oestrous cycle (Peters, Lamming \& Fisher, 1981; Text-fig. 3). This restoration of LH episodes 


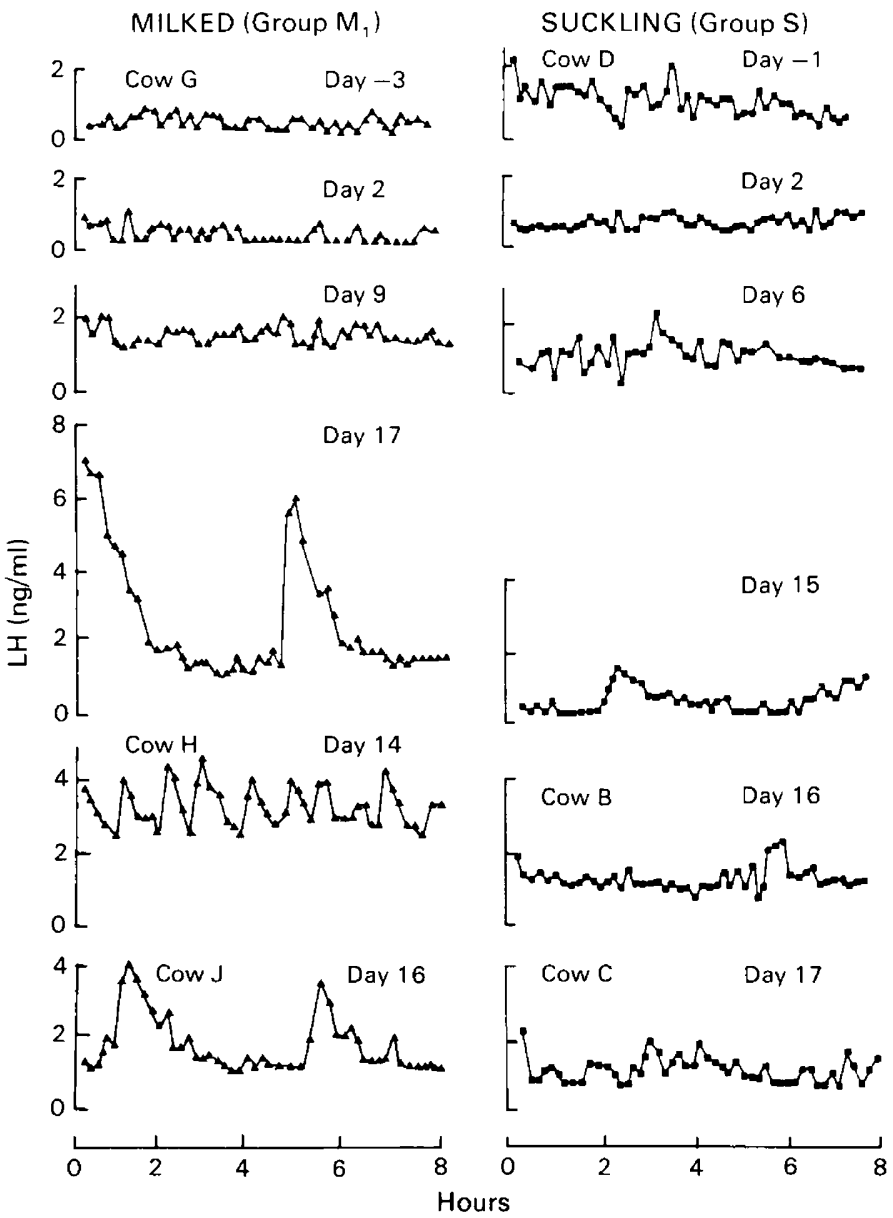

Text-fig. 3. Individual 8-h profiles of $\mathrm{LH}$ concentrations in representative cows from Group $M_{1}$ (milked) and Group $S$ (suckling) pre and post partum. Note the low levels and lack of episodes up to Day 9 post partum and the development of a pulsatile pattern in Cows $G, H$ and $J$ of Group $M_{1}$ between Days 14 and 17. Cow $\mathrm{H}$ exhibits a greater frequency of LH pulses, typical of the follicular phase, than do Cows $G$ and $J$ (typical of the luteal phase), while the suckling Cows D, B and C have lower. LH levels and few pulses at this time. (From Peters et al., 1981.)

precedes any resumption of ovarian activity; indeed cows will only start to cycle when this pattern becomes typical of the follicular phase of the oestrous cycle. In the more deeply anoestrous suckled cow with an extended post-partum interval, plasma LH levels are low and there is a corresponding delay in the restoration of episodic LH secretion, to such an extent that there is a significant correlation between the interval from parturition to the onset of episodic secretion and the length of the anovulatory period (Riley, 1982). However, changes in FSH secretion do not appear to be as critical for the resumption of ovarian activity. Insufficient data yet exist to explain the absence of LH episodes in the post-partum cow, although the much longer interval to the restoration of episodic LH secretion in the suckled compared to the milked cow indicates a possible inhibition attributable to the suckling stimulus. Schallenberger \& Peterson (1982) have demonstrated that, although increased sensitivity to the negative feedback effects of oestradiol may partly explain the absence of $\mathrm{LH}$ episodes, there is also a general reduction in hypothalamic activity in the postpartum cow. Furthermore, in some deeply anoestrous multiple suckled cows it is possible to find a 
pattern of episodic LH secretion similar to that found during the follicular phase of the oestrous cycle, yet these animals still remain anovulatory. The possible reasons for this will be discussed.

Although episodic LH secretion has been observed in all sows during lactation, a significant increase in LH episode rate and mean LH concentration occurs at weaning (Edwards \& Foxcroft, 1983; H. J. Shaw \& G. R. Foxcroft, unpublished data; Text-fig. 4). In some sows this rise in LH secretion resulted in a sustained elevation of the LH baseline and was associated with an early return to oestrus; those sows which responded most effectively to the stimulus of weaning appeared to be those which demonstrated the highest level of episodic LH secretion during lactation. Moreover, in these sows the enhanced pattern of episodic LH secretion was associated with active follicular growth and steroidogenesis, as evidenced by detectable increases in oestradiol secretion; it is possible that in such cases the presence of the litter and/or the suckling stimulus, acting via higher brain centres, inhibit the positive feedback action of oestradiol on the hypothalamus (Elsaesser \& Parvizi, 1980). In the majority of sows, however, lactational anoestrus and anovulation appear to be related more to a direct inhibition of tonic LH secretion itself.

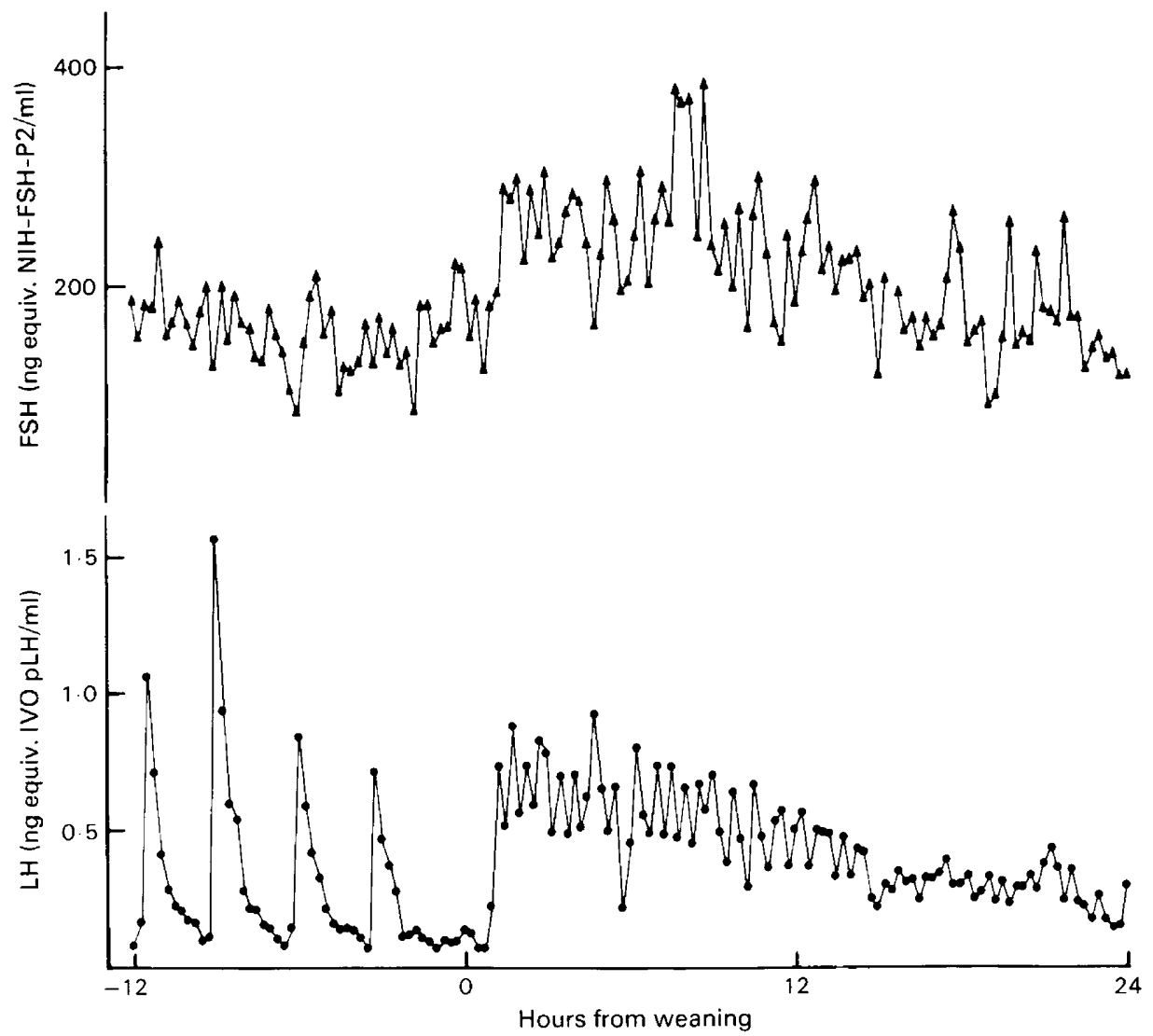

Text-fig. 4. Plasma LH and FSH changes in a sow weaned at 21 days of lactation (H. J. Shaw \& G. R. Foxcroft, unpublished data).

\section{Seasonal anoestrus}

Episodic LH secretion is not completely absent in the anoestrous ewe, although the frequency of LH discharges never reaches that observed during the follicular phase of the oestrous cycle and, particularly in breeds with a deep seasonal anoestrus, may even be lower than that found during the 
luteal phase (Scaramuzzi \& Martenz, 1975; Scaramuzzi \& Baird, 1979; McLeod, Haresign \& Lamming, 1982a, b). In contrast, FSH concentrations, at least in breeds with a relatively shallow anoestrus, are comparable to mid-cycle concentrations (McNeilly, O'Connell \& Baird, 1982). This reduction in LH episode frequency during seasonal anoestrus appears to be mediated by an increased sensitivity to the negative feedback effects of low levels of oestradiol at the hypothalamic-pituitary axis (Karsch et al., 1978; Haresign, McLeod \& Webster, 1983).

\section{Prepubertal period}

Extensive data have been presented from studies in the ewe lamb which are consistent with the hypothesis than an increase in tonic LH secretion acts as the ultimate trigger for preovulatory follicle growth and steroidogenesis (see Ryan \& Foster, 1980). Both an increase in the episodic pattern of LH secretion and a chronic increase in mean concentrations precedes the first ovulation. In lambs attaining puberty naturally the increase in episodic LH release is postulated to be due to a seasonal decrease in sensitivity to oestradiol negative feedback. Furthermore, during this period of anovulation the lack of an effective positive feedback response to oestrogen does not appear to be a major limitation (Squires, Scaramuzzi, Caldwell \& Inskeep, 1972; Foster \& Karsch, 1975).

In the gilt there is also a gradual increase in the rate of episodic LH secretion as the animals approach puberty (Stickney, 1982). Although no precise seasonal change in feedback sensitivity is present, the advent of an LH episodic frequency of 1 per hour may again trigger the first phase of follicular maturation which results in the first LH surge. In view of the gradual increase in circulating oestradiol during the late prepubertal period in the gilt it is possible that the episodic centre of the hypothalamus becomes increasingly influenced by the feedback effects of this steroid in modulating an increase in episodic frequency. Attempts to associate boar-induced precocious puberty with a marked increase in episodic LH activity have produced apparently paradoxical results: the response to boar stimulation appears to be expressed as a general suppression of episodic LH activity although the net effect appears to be an overall increase in basal $\mathrm{LH}$ secretion rates (A. M. Paterson \& G. R. Foxcroft, unpublished data).

\section{Responses to manipulation of tonic LH secretion}

If, as suggested earlier, an increase in the frequency of episodic LH secretion during the follicular phase of the oestrous cycle is responsible for driving the development of the preovulatory follicle(s), then it is possible that the inadequate pattern of episodic LH secretion may be causally related to, rather than merely a symptom of, the various states of anoestrus and ovulation listed. In an attempt to answer this question several experiments have been performed in which the responses to a modification of the tonic LH status of animals following Gn-RH administration have been monitored.

\section{Pulsed injections of $\mathrm{Gn}-\mathrm{RH}$}

The results presented in Table 1 and Text-fig. 5 indicate that increasing the LH episode frequency of seasonally anoestrous Clun Forest ewes from its pretreatment value of $1.5 \pm 0.2$ episodes per $12 \mathrm{~h}$ up to a value of 1 episode per $2 \mathrm{~h}$ was sufficient to induce the sequence of hormonal changes which result in a preovulatory LH surge and ovulation (McLeod et al., 1982b). The ewes were injected intravenously with a range of Gn-RH doses (75-500 ng/injection) which induced LH episodes typical in magnitude to those found naturally, rather than the immediate preovulatory-type $\mathrm{LH}$ surge which follows treatment with much larger dose $(150-300 \mu \mathrm{g})$, singlebolus injections (Haresign, Foster, Haynes, Crighton \& Lamming, 1975). The data in Text-fig. 5 indicate that these low doses of Gn-RH did not result in the pituitary becoming refractory to 
Table 1. Ovulation rate, characteristics of $\mathrm{LH}$ release and the incidence of luteal function in seasonally anoestrous ewes (5/group, Groups 1-5; 10 in Group 6;2 in Group 7) treated with small-dose multiple injections of Gn-RH at 2-h intervals for $48 \mathrm{~h}$ (after McLeod et al., 1982b)

\begin{tabular}{|c|c|c|c|c|c|c|c|c|}
\hline \multirow[b]{2}{*}{ Group } & \multirow[b]{2}{*}{$\begin{array}{r}\text { Gn-RH } \\
(\mathrm{ng} / 2 \mathrm{~h})\end{array}$} & \multirow[b]{2}{*}{$\begin{array}{l}\text { Ovulation } \\
\text { rate }\end{array}$} & \multirow[b]{2}{*}{$\begin{array}{l}\text { Mean maximum } \\
\text { conc. of the } \\
\text { first } 8 \mathrm{Gn}-\mathrm{RH}- \\
\text { induced } \\
\text { episodes } \\
(\mathrm{ng} / \mathrm{ml})\end{array}$} & \multicolumn{3}{|c|}{ Preovulatory LH surge } & \multicolumn{2}{|c|}{$\begin{array}{l}\text { Incidence of luteal } \\
\text { function }\end{array}$} \\
\hline & & & & $\begin{array}{l}\text { Time from } \\
\text { 1st Gn-RH } \\
\text { injection to } \\
\text { onset of surge } \\
\text { (h) }\end{array}$ & $\begin{array}{l}\text { Duration of } \\
\text { surge (h) }\end{array}$ & $\begin{array}{l}\text { Maximum } \\
\text { conc. } \\
(\mathrm{ng} / \mathrm{ml})\end{array}$ & Normal & $\begin{array}{l}\text { Delayed (or } \\
\text { abnormal }{ }^{*} \text { ) }\end{array}$ \\
\hline 1 & 75 & $1 \cdot 20 \pm 0.20$ & $4 \cdot 77 \pm 0.44^{a}$ & $21.80 \pm 6.99^{c}$ & $16.20 \pm 0.88$ & $146 \cdot 5 \pm 15 \cdot 4$ & 1 & $1\left(+1^{*}\right)$ \\
\hline 2 & 125 & $1.40 \pm 0.24$ & $4.93 \pm 0.38^{\mathrm{a}}$ & $22.90 \pm 5.59^{\circ}$ & $16 \cdot 50 \pm 0.76$ & $176.0 \pm 22.7$ & 2 & 1 \\
\hline 3 & 250 & $1.80 \pm 0.37$ & $7.74 \pm 0.74^{b}$ & $17.70 \pm 0.70^{c}$ & $14.50 \pm 0.80$ & $213.6 \pm 18.3$ & 1 & \\
\hline 4 & 500 & $1.50 \pm 0.29+$ & $7.40 \pm 0.55^{b}$ & $20 \cdot 40 \pm 1.48^{c}$ & $13.75 \pm 1.06$ & $174.8 \pm 13.5$ & 1 & \\
\hline 5 & $250 \S$ & $\zeta_{1.73+0.15}$ & $6.21 \pm 0.47^{b}$ & $33.89+1.75+d$ & $13.77+0.70 t$ & $166.0 \pm 19.3+$ & 5 & \\
\hline 6 & $250 \S$ & $1.73 \pm 0.15$ & - & $33.89 \pm 1.75+$ & $13.77 \pm 0.70 \ddagger$ & & 10 & \\
\hline 7 & $\begin{array}{l}\text { Saline } \\
\text { only }\end{array}$ & - & - & - & & & - & \\
\hline
\end{tabular}

* One ewe showed only a transient rise in progesterone.

$\dagger$ Excluding one ewe which failed to ovulate.

$\ddagger$ Excluding one ewe in which no LH peak was observed during the period of treatment but which did ovulate.

$\S$ Ewes pretreated with progesterone implants for 12 days before $\mathrm{Gn}-\mathrm{RH}$ injections.

Within columns, means with different superscripts are significantly different: $\mathrm{a}-\mathrm{b}, P<0.05 ; \mathrm{c}-\mathrm{d}, P<0.001$.

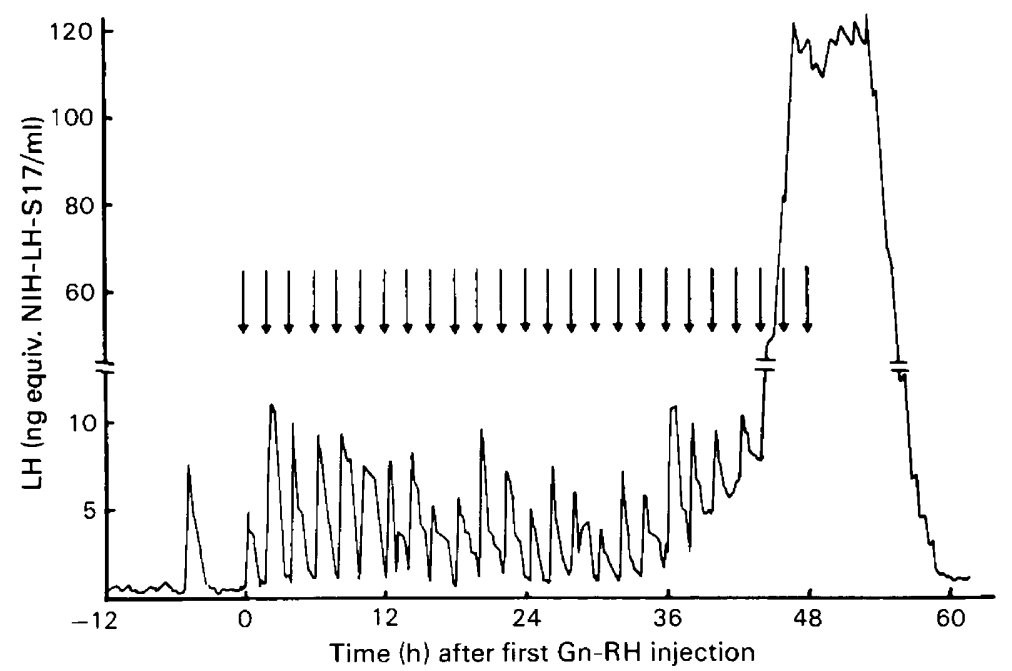

Text-fig. 5. Plasma LH concentrations in a seasonally anoestrous ewe injected with $250 \mathrm{ng} \mathrm{Gn}$ RH ( $\downarrow$ ) every $2 \mathrm{~h}$ for $48 \mathrm{~h}$ (B. J. McLeod \& W. Haresign, unpublished data).

repeated stimulation over the 48-h treatment period. The induced preovulatory $\mathrm{LH}$ surge did not appear to result directly from the Gn-RH injections but rather by the positive feedback action of oestrogen from developing follicles. All 15 ewes pretreated with progesterone came into oestrus at a mean time of $34.7 \pm 2.6 \mathrm{~h}$ after the first $\mathrm{Gn}-\mathrm{RH}$ injection (a phenomenon known to require an increment of oestrogen); all were mated to entire rams and 11 ewes successfully carried a pregnancy to term. The ability of the induced rise in episodic $\mathrm{LH}$ secretion to drive the final stages of follicular development and precipitate the hormonal changes essential for ovulation support the findings of Ryan \& Foster (1980) in which hourly injections of purified LH induced precocious puberty in ewe lambs. Although Gn-RH will release both LH and FSH (Lincoln, 1979) it seems 
likely that the responses noted were attributable to the induced changes in LH secretion alone since injection of purified LH into seasonally anoestrous Finn $\times$ Merino (McNeilly et al., 1982) and Romney ewes (McNatty, Gibb, Dobson \& Thurley, 1981) produces similar results.

Of particular interest in the data presented in Table 1 is the incidence of luteal function following ovulation. Only 5 out of 20 ewes treated with $\mathrm{Gn}-\mathrm{RH}$ alone produced normal corpora lutea, with a further 5 ewes showing limited evidence of progesterone secretion. It is possible that this may reflect differences in stage of development of individual follicles when Gn-RH treatment began, since Hammond (1944), Robinson (1950) and Matton, Bherer \& Dufour (1977) have all reported continual phases of early growth and atresia in follicles in the anoestrous ewe. In addition, the timing of the preovulatory LH surge would also seem to be important. Considered over all treatment groups this occurred $35.9 \pm 1.5 \mathrm{~h}$ after the first $\mathrm{Gn}-\mathrm{RH}$ injection in those ewes with subsequent normal luteal function compared to $22 \cdot 0 \pm 1 \cdot 1 \mathrm{~h}(P<0.001)$ in those ewes in which there was no significant rise in progesterone following ovulation. Progesterone pretreatment resulted in all ewes falling into the former category. During the natural oestrous cycle progesterone is known to be important in organizing the endocrine events which culminate in the final phases of follicular growth and ovulation immediately following luteal regression. The responses noted here reflect this, although whether it is a direct action of progesterone at the ovarian level to 'hold' follicles at a particular stage of development or an indirect effect via modification of endogenous gonadotrophin secretion requires further study.

Similar studies of the post-partum cow indicate that 2 hourly injection of $5 \mu \mathrm{g} \mathrm{Gn}-\mathrm{RH}$ for $48 \mathrm{~h}$ will induce an episodic pattern of LH secretion, which eventually culminates in a preovulatory LH

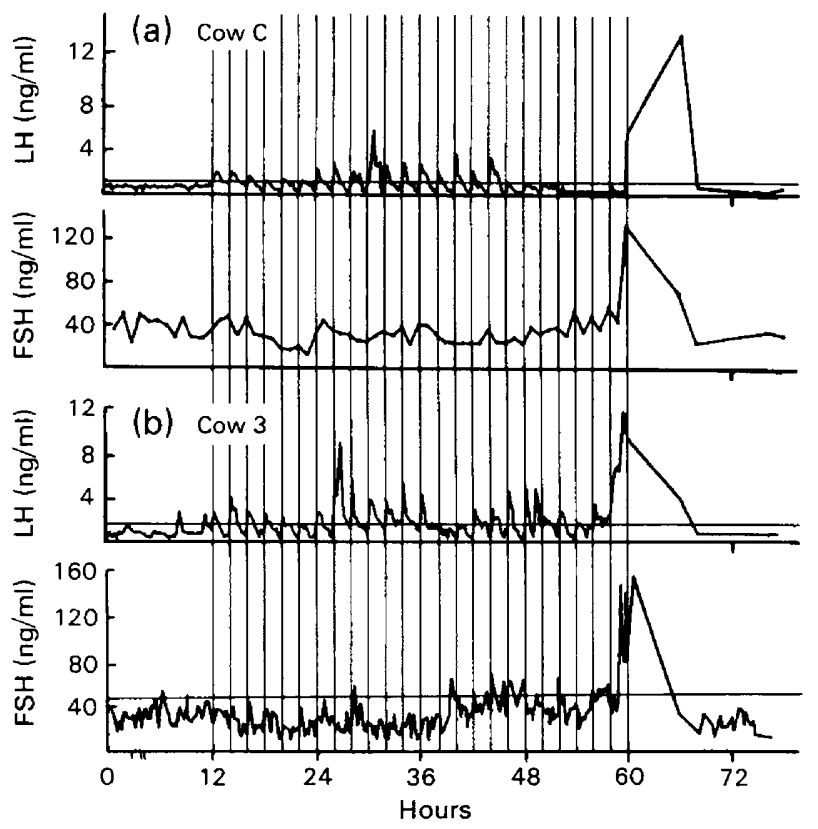

Text-fig. 6. Plasma LH (NIH-B9) and FSH (NIH-B1) concentrations in 2 post-partum cows for $12 \mathrm{~h}$ before, during, and for $18 \mathrm{~h}$ after injections of Gn-RH every $2 \mathrm{~h}$ for $48 \mathrm{~h}$. The timing of $\mathrm{Gn}-\mathrm{RH}$ injections is indicated by the vertical lines. The injections caused regular pulsatile increases in LH concentrations in both cows although the response declined after about $36 \mathrm{~h}$ in Cow $\mathrm{C}$ and eventually ceased 6-8 h before the $\mathrm{LH}$ surge. There was no pulsatile response of FSH to the Gn-RH injections. Horizontal lines indicate 2 standard deviations above the mean pre-injection concentration and all values above these lines are considered to be significant elevations above the mean. (From Riley et al., 1981.) 
surge, ovulation and luteal function (Riley, Peters \& Lamming, 1981; Text-fig. 6). Unlike LH, FSH did not respond with discrete episodes to the repeated $\mathrm{Gn}-\mathrm{RH}$ injections and there was a significant depression in FSH concentration over the first $12 \mathrm{~h}$ of treatment compared with the pretreatment control period, and a significant rise over the fourth 12-h period of Gn-RH treatment and a preovulatory FSH surge occurred coincident with the LH surge.

These data confirm that, at least in some anoestrous animals, anovulation is attributable to a lack of episodic LH secretion rather than a general gonadotrophin insufficiency. Furthermore, in the cow, progesterone pretreatment did not appear to be a prerequisite for the induced ovulations to develop into normal corpora lutea, as it is in the sheep. To date little evidence is available to indicate whether similar treatment will induce ovulation in the reproductively inactive pig, although studies of lactating sows and prepubertal gilts suggest that oestrus and ovulation can be induced by pulsed injections of Gn-RH (Carpenter \& Anderson, 1981; J. H. Britt, personal communication).

\section{Continuous infusion of $\mathrm{Gn}-\mathrm{RH}$}

The above studies raise the important question of whether it is the episodic pattern of LH secretion per se or merely the increase in mean circulating LH concentrations which such a pattern produces which is important at the ovarian level. Seasonally anoestrous ewes and post-partum cows have therefore been given continuous infusions of low doses of $\mathrm{Gn}-\mathrm{RH}$ in an attempt to produce a chronic elevation in mean LH concentrations. Two groups of 12 seasonally anoestrous ewes were infused intravenously with 125 or $250 \mathrm{ng} \mathrm{Gn}-\mathrm{RH} / \mathrm{h}$ for $48 \mathrm{~h}$ after a 12-day pretreatment period with progesterone. The results are presented in Tables 2 and 3 and Text-fig. 7. Infusion of Gn-RH

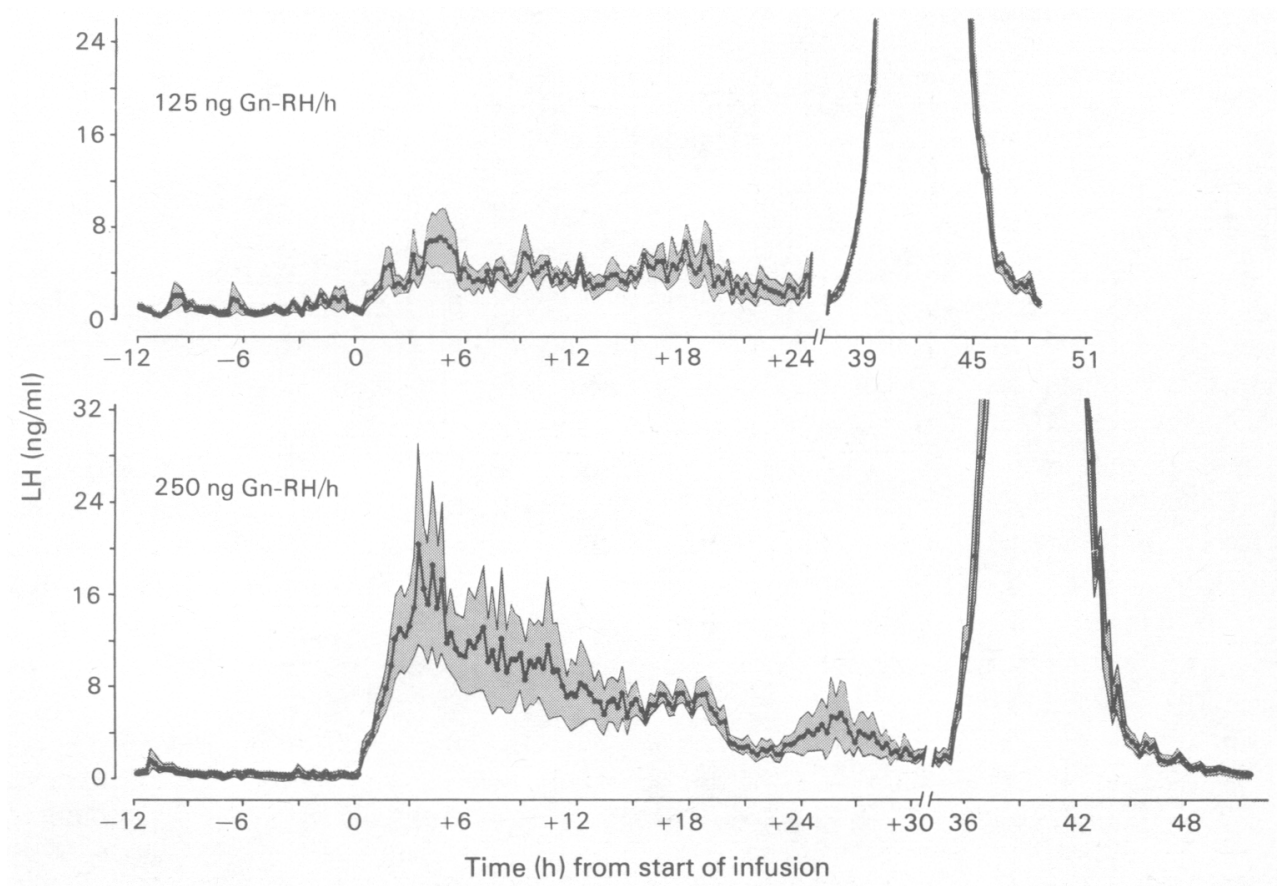

Text-fig. 7. Mean plasma LH concentrations of two groups of 5 progesterone-primed seasonally anoestrous ewes infused intravenously with 125 or $250 \mathrm{ng} \mathrm{Gn}-\mathrm{RH} / \mathrm{h}$ for $48 \mathrm{~h}$ after removal of progesterone implants. The solid line indicates the group mean and the s.e.m. is indicated by the shaded area bounded by the fine lines. (From McLeod et al., 1983.) 
Table 2. Oestrus, ovulation rate and preovulatory $\mathrm{LH}$ release in progesterone-primed seasonally anoestrous ewes given a continuous intravenous infusion of Gn-RH for $48 \mathrm{~h}$ (after McLeod et al., 1983)

\begin{tabular}{cccccc}
\hline Group & $\begin{array}{c}\text { Gn-RH } \\
(\mathrm{ng} / \mathrm{h})\end{array}$ & $\begin{array}{c}\text { No. ewes } \\
\text { ovulating }\end{array}$ & $\begin{array}{c}\text { Ovulation } \\
\text { rate }\end{array}$ & $\begin{array}{c}\text { No. of ewes } \\
\text { in oestrus }\end{array}$ & $\begin{array}{c}\text { Interval from } \\
\text { start of treatment } \\
\text { to preovulatory } \\
\text { LH peak (h) }\end{array}$ \\
\hline 1 & 125 & $11 / 12^{*}$ & $1.27 \pm 0.14$ & $10 / 12^{*}$ & $36 \cdot 1 \pm 2.9$ \\
2 & 250 & $12 / 12$ & $1.75 \pm 0.22$ & $12 / 12$ & $34.7 \pm 2.0$ \\
3 & 0 & $0 / 4$ & - & - & \pm \\
\hline
\end{tabular}

* One ewe lost its progesterone implants before $\mathrm{Gn}-\mathrm{RH}$ infusion and another was infused subcutaneously not intravenously.

Table 3. Mean ( \pm s.e.m.) plasma $\mathrm{LH}$ concentrations $(\mathrm{ng} / \mathrm{ml})$ in progesteroneprimed seasonally anoestrous ewes infused with $125 \mathrm{ng} \mathrm{Gn-RH/h,} 250 \mathrm{ng}$ Gn$\mathrm{RH} / \mathrm{h}$ or saline for $48 \mathrm{~h}$ (after McLeod et al., 1983).

\begin{tabular}{cccccccc}
\hline & & \multicolumn{4}{c}{ Period in relation to the start of infusion } \\
\cline { 3 - 7 } Group & $\begin{array}{c}\text { No. of } \\
\text { ewes }\end{array}$ & $\begin{array}{c}\text { Gn-RH } \\
(\mathrm{ng} / \mathrm{h})\end{array}$ & -12 to $0 \mathrm{~h}$ & 0 to $12 \mathrm{~h}$ & 12 to $24 \mathrm{~h}$ & $\begin{array}{c}\text { Start of infusion } \\
\text { to onset of } \mathbf{L H} \\
\text { peak }\end{array}$ \\
\hline 1 & $10^{*}$ & 125 & $1.07 \pm 0.09^{\mathrm{a}}$ & $6.76 \pm 1 \cdot 27^{\mathrm{b}}$ & $5.05 \pm 0.90^{\mathrm{b}}$ & $5.60 \pm 0.81^{\mathrm{b}}$ \\
2 & $11^{\dagger}$ & 250 & $1.08 \pm 0.58^{\mathrm{a}}$ & $14.49 \pm 2.22^{\mathrm{b}, \mathrm{c}}$ & $8.92 \pm 2.07^{\mathrm{b}}$ & $11 \cdot 37 \pm 2.03^{\mathrm{b}, \mathrm{d}}$ \\
3 & 4 & saline & $0.88 \pm 0.24^{\mathrm{a}}$ & $1.21 \pm 0.22^{\mathrm{a}}$ & $1.11 \pm 0.19^{\mathrm{a}}$ & $1.21 \pm 0.15^{\mathrm{a}}$ \\
\hline
\end{tabular}

* Excludes one ewe which lost its progesterone implants before treatment and another which was infused subcutaneously rather than intravenously.

† Excludes one ewe in which the preovulatory LH peak was not monitored during the frequent blood sampling period. Within columns, means with different superscripts are significantly different: a-b, $P<0.001 ; \mathrm{b}-\mathrm{c}, P<0.01 ; \mathrm{b}-\mathrm{d}, P<0.05$.

resulted in a sustained increase in mean LH levels, the order of magnitude of which was significantly influenced by dose of $\mathrm{Gn}-\mathrm{RH}$, and eventually culminated in a preovulatory $\mathrm{LH}$ surge. Excluding the 2 ewes in which the treatment was found to be incorrect (due to lost progesterone implants or a subcutaneous rather than an intravenous infusion) all ewes ovulated and produced viable corpora lutea (McLeod et al., 1983). Studies using infusion rates of $0.5-2.5 \mu \mathrm{g} / \mathrm{h}$ for $48 \mathrm{~h}$ in post-partum cows have produced similar responses (A. R. Peters \& G. E. Lamming, unpublished data). Collectively these results indicate that an increase in mean circulating levels of $\mathrm{LH}$ rather than the episodic pattern per se may be important at the ovarian level. Furthermore, the continuous elevation in tonic LH secretion resulting from continuous infusion of low doses of Gn-RH did not appear to result in 'down regulation' at the pituitary (see McLeod et al., 1983), although in these studies the infusion rate was lower and the infusion period relatively short compared to that used in the monkey (Knobil, 1980).

Although the results presented so far have suggested the lack of episodic LH secretion as the underlying cause of seasonal and post-partum anoestrus, this may not be the sole cause of these periods of anovulation. The depth of post-partum anoestrus is greater in multiple than in single suckled cows, and this is reflected in their different responses to repeated injections of low doses of Gn-RH. Although the deeply anoestrous multiple suckled cow will produce the typical pattern of episodic LH secretion in response to Gn-RH treatment (Text-fig. 8), the majority of such animals do not produce a spontaneous preovulatory LH surge and ovulate (M. W. Fisher, A. R. Peters \& G. E. Lamming, unpublished data). Similarly, the Scottish Blackface ewe, a breed with a very deep 


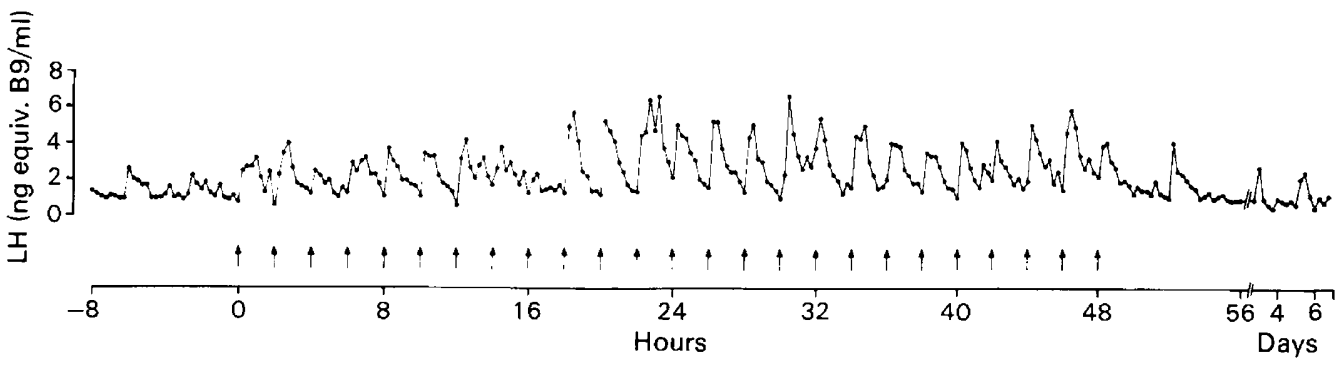

Time from beginning of treatment

Text-fig. 8. Plasma LH concentrations at 90 days post partum in a Friesian cow suckling 4 calves. The samples were taken at 15-min intervals for $8 \mathrm{~h}$ before, for $48 \mathrm{~h}$ during and $8 \mathrm{~h}$ after 2-h i.v. injections of $2.5 \mu \mathrm{g} \mathrm{Gn-RH;} \mathrm{6-h} \mathrm{plasma} \mathrm{samples} \mathrm{were} \mathrm{then} \mathrm{taken} \mathrm{for} \mathrm{a} \mathrm{further} 5$ days. Note (i) the pulsatile $\mathrm{LH}$ response to each injection of $\mathrm{Gn}-\mathrm{RH}$, (ii) no consistent change in basal LH level during Gn-RH treatment, and (iii) no subsequent preovulatory LH surge.

seasonal anoestrus, will not respond to the repeated LH injections which McNeilly et al. (1982) found so successful for the Finn $\times$ Merino ewe (A. S. McNeilly, personal communication). It is clear that in both of these situations anovulation was due, at least in part, to some component other than an inadequate pattern of episodic LH secretion, although whether the block was at the ovarian or hypothalamo-pituitary level requires further study. It is possible that in these deeply anoestrous conditions endogenous gonadotrophin secretion is so low that the early stages of follicular growth are impaired to such an extent that there are no follicles present which can respond fully to the $\mathrm{LH}$ stimulus. Alternatively, the positive feedback centre of the hypothalamus may be so reduced in its sensitivity that it is incapable of responding to oestradiol from the developing follicles to promote the preovulatory LH surge. The former seems the more likely possibility because (1) few reports have shown a marked seasonal change in oestrogen positive feedback in the ewe, and (2) although suckling has been shown to reduce the positive feedback response to oestradiol injections in the cow (Radford, Nancarrow \& Mattner, 1978; Short, Randel, Staigmiller \& Bellows, 1979), this appears to be restricted to the very early post-partum period. Further study is therefore required to determine why such deeply anoestrous animals do not respond to treatments designed to increase their tonic LH secretion.

\section{Conclusions}

When compared to the follicular phase of the oestrous cycle, the various anovulatory conditions encountered in farm species appear to be associated with a pattern of suppressed episodic LH secretion which is ineffective in promoting a sequence of follicular growth and steroidogenesis that culminates in ovulation and normal luteal function. Correction of this inadequacy by repeated injections of low doses of purified LH or synthetic Gn-RH can restore normal reproductive activity. However, in the deeply anoestrous animal, this alone is insufficient to promote follicular growth and ovulation, suggesting that some additional hormonal inadequacy is contributing to such anovulatory conditions. The success achieved with continuous infusion rather than pulsed injections of Gn-RH indicates that it may be the increase in mean circulating $\mathrm{LH}$ concentrations, rather than the episodic pattern per se which is required to promote follicular activity in the quiescent ovary of domestic farm species.

Whatever the explanation for the failure of pulsed injections or continuous infusion of low doses of Gn-RH to induce ovulation in some deeply anoestrous animals, the adequate responses which have been obtained generally in the studies reported above illustrate the possibility of using Gn-RH to induce ovulation during periods of seasonal or post-partum anovulation. 


\section{References}

Baird, D.T. (1978) Pulsatile secretion of LH and ovarian estradiol during the follicular phase of the sheep estrous cycle. Biol. Reprod. 18, 359-364.

Baird, D.T., Swanston, I. \& Scaramuzzi, R.J. (1976) Pulsatile release of $\mathrm{LH}$ and secretion of ovarian steroids in sheep during the luteal phase of the estrous cycle. Endocrinology 98, 1490-1496.

Bulman, D.C. \& Lamming, G.E. (1978) Milk progesterone levels in relation to conception, repeat breeding and factors influencing acyclicity in dairy cows. $J$. Reprod. Fert. 54, 447-458.

Bulman, D.C. \& Wood, P.D.P. (1980) Abnormal patterns of ovarian activity in dairy cows and their relationships with reproductive performance. Anim. Prod. 30, 177-188

Carpenter, L.S. \& Anderson, L.L. (1981) Pulsatile infusion of gonadotropin releasing-hormone on luteinizing hormone secretion and ovarian function in prepubertal gilts. J. Anim. Sci. 53, Suppl. 1, 301, Abstr. 436.

Edwards, S. \& Foxcroft, G.R. (1983) Endocrine changes in sows weaned at two stages of lactation. J. Reprod. Fert. 67, 161-172.

Elsaesser, F. \& Parvizi, N. (1980) Partial recovery of the stimulatory oestrogen feedback action on $\mathrm{LH}$ release during late lactation in the pig. J. Reprod. Fert. 59, 63-67.

Fernandes, L.C., Thatcher, W.W., Wilcox, C.J. \& Call, E.P. (1978) LH release in response to Gn-RH during the post-partum period of dairy cows. J. Anim. Sci. 46, 443-448.

Foster, D.L. \& Karsch, F.J. (1975) Development of the mechanism regulating the preovulatory surge of luteinizing hormone in the sheep. Endocrinology 97, 1205-1209.

Foster, J.P., Lamming, G.E. \& Peters, A.R. (1980) Shortterm relationships between plasma $\mathbf{L H}$, FSH and progesterone concentrations in post-partum dairy cows and the effect of Gn-RH injection. J. Reprod. Fert. 59, 321-327.

Foxcroft, G.R. \& van de Wiel, D.F.M. (1982) Endocrine control of the oestrous cycle. In Control of Pig Reproduction, Ch. 8, pp. 161-177. Eds D. J. A. Cole \& G. R. Foxcroft. Butterworths, London.

Hammond, J. (1944) On the breeding season in sheep. $J$. agric. Sci., Camb. 34, 97-105.

Haresign, W., Foster, J.P., Haynes, N.B., Crighton, D.B. \& Lamming, G.E. (1975) Progesterone levels following treatment of seasonally anoestrous ewes with synthetic LH-releasing hormone. J. Reprod. Fert. 43, 269-279.

Haresign, W., McLeod, B.J. \& Webster, G.M. (1983) Endocrine control of reproduction in the ewe. In Sheep Production, pp. 353-379. Ed. W. Haresign. Butterworths, London.

Jenkin, G., Heap, R.B. \& Symons, D.B.A. (1977) Pituitary responsiveness to synthetic LH-RH and pituitary $\mathrm{LH}$ content at various reproductive stages in the sheep. J. Reprod. Fert. 49, 207-214.

Karsch, F.J., Legan, S.J., Ryan, K.D. \& Foster, D.L. (1978) The feedback effects of ovarian steroids on gonadotrophin secretion. In Control of Ovulation, pp.
29-48. Eds D. B. Crighton, N. B. Haynes, G. R. Foxcroft \& G. E. Lamming. Butterworths, London.

Knobil, E. (1980) The neuroendocrine control of the menstrual cycle. Recent Prog. Horm. Res. 36, 53-58.

Lamming, G.E., Wathes, D.C. \& Peters, A.R. (1981) Endocrine patterns of the post-partum cow. $J$. Reprod. Fert., Suppl. 30, 155-170.

Lincoln, G.A. (1979) Use of pulsed infusion of luteinizing hormone-releasing hormone to mimic seasonally induced endocrine changes in the ram. J. Endocr. 83, 251-260.

Matton, P., Bherer, J. \& Dufour, J.J. (1977) Morphology and responsiveness of the two largest ovarian follicles in anoestrous ewes. Can. J. Anim. Sci. 57, 459464.

McLeod, B.J., Haresign, W. \& Lamming, G.E. (1982a) The induction of ovulation and luteal function in seasonally anoestrous ewes treated with small-dose multiple injections of Gn-RH. J. Reprod. Fert. 65, 215-221.

McLeod, B.J., Haresign, W. \& Lamming, G.E. (1982b) Response of seasonally anoestrous ewes to small-dose multiple injections of $\mathrm{Gn}-\mathrm{RH}$ with and without progesterone pretreatment. J. Reprod. Fert. 65, 223230.

McLeod, B.J., Haresign, W. \& Lamming, G.E. (1983) Induction of ovulation in seasonally anoestrous ewes by continuous infusion of low doses of Gn-RH. $J$. Reprod. Fert. 68, 489-495.

McNatty, K.P., Gibb, M., Dobson, C. \& Thurley, D.C. (1981) Evidence that changes in luteinizing hormone secretion regulates the growth of the preovulatory follicle in the ewe. J. Endocr. 90, 375-389.

McNeilly, A.S., O'Connell, M. \& Baird, D.T. (1982) Induction of ovulation and normal luteal function by pulsed injections of luteinizing hormone in anestrous ewes. Endocrinology 110, 1292-1299.

Paterson, A.M., Barker, I. \& Lindsay, D.R. (1978) Summer infertility in pigs: its incidence and characteristics in an Australian commercial piggery. $J$. exp. Agric. Anim. Husb. 18, 691-698.

Peters, A.R. \& Riley, G.M. (1982a) Milk progesterone profiles and factors affecting post-partum ovarian activity in beef cows. Anim. Prod. 34, 145-153.

Peters, A.R. \& Riley, G.M. (1982b) Is the cow a seasonal breeder? Br. vet. J. 138, 533-537.

Peters, A.R., Lamming, G.E. \& Fisher, M.W. (1981) A comparison of plasma LH concentrations in milked and suckling post-partum cows. J. Reprod. Fert. 62 , 567-573.

Radford, H.M., Nancarrow, C.D. \& Mattner, P.E. (1978) Ovarian function in suckling and non-suckling beef cows post partum. J. Reprod. Fert. 54, 49-56.

Rahe, C.M., Owens, R.E., Fleeger, J.L., Newton, H.J. \& Harms, P.G. (1980) Pattern of plasma luteinizing hormone in the cyclic cow: dependence upon the period of the cycle. Endocrinology 107, 498-503.

Richards, J.S., Rao, M.C. \& Ireland, J.J. (1978) Actions of pituitary gonadotrophins on the ovary. In Control of Ovulation, pp. 197-216. Eds D. B. Crighton, N. B. Haynes, G. R. Foxcroft \& G. E. Lamming. Butterworths, London. 
Riley, G.M. (1982) Reproductive endocrinology of the postparsurient beef cow. Ph.D. thesis, University of Nottingham.

Riley, G.M., Peters, A.R. \& Lamming, G.E. (1981) Induction of pulsatile $\mathrm{LH}$ release, FSH release and ovulation in post-partum beef cows by repeated small doses of Gn-RH. J. Reprod. Fert. 63, 559-565.

Robinson, T.J. (1950) The control of fertility in sheep. $J$. agric. Sci., Camb. 40, 275-307.

Robinson, T.J. (1951) Reproduction in the ewe. Biol. Rev. 26, $121-157$.

Ryan, K.D. \& Foster, D.L. (1980) Neuroendocrine mechanisms involved in onset of puberty in the female: concepts derived from the lamb. Fedn Proc. Fedn Am. Socs exp. Biol. 39, 2372-2377.

Scaramuzzi, R.J. \& Baird, D.T. (1979) Ovarian steroid secretion in sheep during anoestrus. In Sheep Breeding, 2nd edn, pp. 463-470. Eds G. J. Tomes, D. E. Robertson, R. J. Lightfoot \& W. Haresign. Butterworths, London.

Scaramuzzi, R.J. \& Martensz, N.D. (1975) Effects of active immunization against androstenedione on luteinizing hormone levels in the ewe. In. Immunisation with Hormones in Reproductive Research, pp. 141163. Ed. E. Nieschlag. North Holland, Amsterdam.

Schallenberger, E. \& Peterson, A.J. (1982) Effect of ovariectomy on tonic gonadotrophin secretion in cyclic and post-partum dairy cows. J. Reprod. Fert. 64, 47-52.

Short, R.E., Randel, R.D., Staigmiller, R.B. \& Bellows, R.A. (1979) Factors affecting estrogen-induced LH release in the cow. Biol. Reprod. 21, 683-689.

Squires, E.L., Scaramuzzi, R.J., Caldwell, B.V. \& Inskeep, E.K. (1972) LH release and ovulation in the prepubertal lamb. J. Anim. Sci. 34, 612-614.

Stevenson, J.S., Cox, N.M. \& Britt, J.H. (1981) Role of the ovary in controlling LH, FSH and prolactin secretion during and after lactation in pigs. Biol. Reprod. 24, 341-353.

Stickney, K. (1982) The physiology of oestrogen-induced puberty in the gilt. Ph.D. thesis, University of Nottingham.

Varley, M.A. (1982) The time of weaning and its effects on reproductive function. In Control of Pig Reproduction, ch. 22, pp. 459-478. Eds D. J. A. Cole \& G. R. Foxcroft. Butterworths, London.

Webb, R., Lamming, G.E., Haynes, N.B., Hafs, H.D. \& Manns, J.G. (1977) Response of cyclic and postpartum suckled cows to injections of synthetic LHRH. J. Reprod. Fert. 50, 203-210.

Wettermann, R.P., Turman, E.J., Wyatt, R.D. \& Totusek, R. (1978) Influence of suckling intensity on reproductive performance of range cows. J. Anim. Sci. 47, 342-346. 